$$
\text { JIME }
$$$$
\text { (Journal of Industrial and Manufacture Engineering) }
$$

Available online http://ojs.uma.ac.id/index.php/jime

\section{Analisa Usabilitas Website Sistem Informasi Akademik Universitas X Menggunakan Nielsen Attributes of Usability (NAU) Questionnaire}

\section{Usability Analysis of University X Academic Information System Website Using Nielsen Attributes Of Usability (NAU) Questionnaire}

\author{
Yuana Delvika1), Chalis Fajri Hasibuan*2), Yudi Daeng Polewangi ${ }^{3)}$ dan M Habibullah4) \\ Program Studi Teknik Industri, Fakultas Teknik. Universitas Medan Area.
}

Diterima: November 2021; Disetujui: November 2021; Dipublikasi: November 2021;

*Coresponding author : chalisjfajri@staff.uma.ac.id

\section{Abstrak}

Usabilitas merupakan aspek yang mengukur seberapa mudah pengguna dapat mempelajari dan menggunakan produk untuk mencapai tujuannya serta tingkat kepuasan pengguna terhadap produk tersebut. Berdasarkan hasil dari studi pendahuluan yang dilakukan dengan penyebaran kuesioner google form secara online terhadap website Sistem Informsi Akademik Universitas X. Dengan alamat. kepada 20 orang sampel, Mahasiswa dalam hal memahami alur navigasi mengalami kesulitan karena menu yang ditampilkan cukup banyak dan memakan banyak langkah. Sehingga menyebabkan keluhan dan jarangnya tingkat pemakaian pada mahasiswa Universitas X. Analisa pada penelitian ini menggunakan NAU kuesioner. Pengujian ini dilakukan dengan cara memberikan beberapa butir pertanyaan dalam 5 kategori usability menurut standar Nielsen's Model. hasil uji korelasi untuk kategori learnability memorability effciency Errors dan satisfaction terhadap usability 0,000<0,05 maka berkorelasi. Untuk angka koefisien korelasi kategori satisfication, error, learnability,memorability dan efficiency terhadap usability memiliki nilai korelasi sangat kuat (0.76 - 0.99 korelasi sangat kuat), Untuk angka koefisien korelasi kategori apa saja terhadap usability memiliki nilai korelasi kuat (0.51 0.75 korelasi kuat), Untuk angka koefisien korelasi kategori apa saja terhadap usability memiliki nilai korelasi cukup (0.26 - 0.50 korelasi cukup).

Kata kunci: Usabilitas, Nielsen attributes of Usability (NAU) Questionnaire, Sistem Informasi Akademik, Mahasiswa Universitas X

\section{Abstract}

Usability is an aspect that measures how easily users can learn and use the product to achieve the goals and the level of user satisfaction toward the product. Based on the results, the preliminary study was conducted by distributing a google form questionnaire online toward the Academic Informasi System website. the 20 samples students in understanding the navigation flow had difficulties because the menus displayed were quite a lot and took a lot of steps. So that caused complaints and the infrequent level of use in University $X$ students. The analysis in this study used the NAU questionnaire method. This test was conducted by giving several questions in 5 categories of usability according to Nielsen's Model standard. This was as an effort to get the results of the Academic Informasi System website usability evaluation by using the Nielsen's Attributes of Usability (NAU) questionnaire. The results of the correlation test for the category of learnability memorability efficiency Errors and satisfaction toward usability was $0.000<0.05$ then categorized correlated. The correlation coefficients number for the categories of satisfaction, error, learnability, memorability, and efficiency on usability had a very strong correlation value (0.76 - 0.99 very strong correlation), for correlation coefficient number in any category on usability had a strong correlation value (0.51 0.75 strong correlation), for correlation coefficient number in any category on usability had a sufficient correlation value (0.26 -0.50 correlation was sufficient).

Keywords : Usability, Nielsen attributes of Usability (NAU) Questionnaire, Academic Informasi System website, Student $\mathrm{X}$

How to Cite: Delvika, Yuana, Hasibuan, Chalis .F, dkk (2021), Analisa Usabilitas Website Sistem Informasi Akademik Universitas X Menggunakan Nielsen Attributes Of Usability (NAU) Questionnaire. JIME (Journal of Industrial and Manufacture Engineering). 5(2): 167 - 175 
Yuana Delvika, Chalis .F Hasibuan dkk, Analisa Usabilitas Website Sistem Informasi Akademik Universitas X Menggunakan Nielsen Attributes Of Usability (NAU) Questionnaire

\section{PENDAHULUAN}

Setiap tahunnya penggunaan teknologi semakin meningkat salah satu fungsinya teknologi diyakini dapat mempermudah pertukaran informasi, mempersingkat proses-proses manual, sistem informasi merupakan bagian dari teknologi sudah banyak digunakan diberbagai organisasi seperti inatansi pemerintah, binis, sekolah, dimana berfungsi untuk mengumpulkan, menyimpan, mengorganisir, dan menyampaikan informasi. Sistem informasi dapat memenuhi kebutuhan umum semua bagian fungsi organisasi, membantu oraganisasi dalam membuat keputusan, Sistem informasi diyakini dapat berpenegaruh untuk kesuksesan dan kelancaran berjalannya organisasi.

Portal Akademik Online Campus Universitas $\mathrm{X}$ yang disingkat menjadi Sistem Informasi Akademik Universitas X merupakan portal yang diakses oleh civitas akademika melalui web browser. Portal ini dapat diakses oleh mahasiswa, dosen pengampu mata kuliah, dosen wali, dosen pembimbing Tugas Akhir, serta civitas akademika yang lain seperti: Bagian Administrasi Akademik (BAA), Program Studi, Perpustakaan, Bagian Kemahasiswaan, dan Bagian Administrasi Umum dan Kepegawaian (BAU). Bagi dosen, fitur yang dapat diakses meliputi fitur Lihat Data Mahasiswa, Persetujuan Pengisian KRS, Persetujuan Pengeditan KRS, Pencarian KRS Mahasiswa, Berita Acara dan Absensi Perkuliahan, Tugas Akhir/Tesis, Profil Dosen, Download Berkas, Upload Berkas, Panduan Dosen, dan Koreksi Nilai serta informasi lainnya. Ketika pengguna mengakses sebuah halaman website, maka pada saat itulah terjadi interaksi antara pengguna dengan komputer atau perangkat yang digunakan untuk membuka atau mengakses web browser tersebut. Interaksi ini biasanya disebut sebagai interaksi antara manusia dengan komputer (human computer interaction).

Berdasarkan hasil dari studi pendahuluan yang dilakukan dengan penyebaran kuesioner google form secara online terhadap website Sistem Informasi Akademik Universitas X.. kepada 20 orang sampel yang terdiri dari 3 responden teknik mesin, 4 responden teknik arsitektur, 2 responden teknik sipil, 4 responden teknik informatika, 3 responden teknik industri, 4 responden teknik elektro yang merupakan mahasiswa fakultas teknik Universitas X . Permasalahan yang ditemukan pada website Sistem Informasi Akademik Universitas $\mathrm{X}$ ini merupakan permasalahan terkait dengan usabilitas yang kurang baik

Berdasarkan penelitian awal umumnya pengguna ingin mendapatkan informasi secara cepat dan sesuai yang diharapkan sehingga mereka tidak mempunyai waktu untuk membaca manual website ataupun terdapatnya ikon pencarian pada website sehingga tidak mencoba coba interface yang tersedia. Keluhan responden juga terdapat pada menu topik berita yang tidak update sehingga para mahasiswa jarang untuk membuka portal tersebut. Dan tidak adanya pusat bantuan informasi pada website tersebut,apabila terjadi kendala atau masalah dalam penggunaan,error dan lain-lain. Sehingga apabila terjadi kendala ataupun masalah pada website tersebut,mahasiswa langsung melaporkan keadaan ini kepada admin prodi masingmasing melalui social media ataupun langsung ke kampus untuk menemui admin prodinya. 
Dari penelitian awal tersebut dapat disimpulkan bahwasanya adanya permasalahan dalam usabilitas Sistem Informasi Akademik Universitas $\mathrm{X}$ di. Sehingga menyebabkan keluhan dan jarangnya tingkat pemakaian pada mahasiswa Universitas X . Maka penulis akan melakukan penelitian dengan judul Analisa Usabilitas Website Sistem Informasi Akademik Universitas $\mathrm{X}$ Menggunakan Metode Nielsen Attributes of Usability (NAU) Questionnaire di Universitas X

\section{METODE PENELITIAN}

Metode NAU merupakan salah satu metode untuk melakukan pengujian kualitatif terkait usability suatu website dengan menggunakan media kuesioner. Pengujian ini dilakukan dengan cara memberikan beberapa butir pertanyaan dalam 5 kategori usability menurut standar Nielsen's Model yaitu Learnability, Memorability, Errors, Satisfaction, dan Efficiency. Nielsen menawarkan berbagai macam cara yang dapat dilakukan untuk melakukan evaluasi usability pada website, salah satunya adalah dengan menggunakan angket Nielsen Atributtes of Usability (NAU) yang memasukkan lima kategori di atas sebagai poin penilaian pengguna terhadap website.

Populasi adalah keseluruhan subyek penelitian, apabila seseorang ingin meneliti semua elemen yang ada dalam wilayah penelitian, maka penelitian populasi atau studi populasi atau study sensus (Sabar, 2007). Dalam menentukan sampel dari suatu populasi yang digunakan dalam melakukan perhitungan atau acuan tabel yang dikembangkan oleh para ahli. Responden adalah orang-orang yang merespon atau menjawab pertanyaan penelitian baik pertanyaan tertulis ataupun pertanyaan lisan (Arikunto, 2003), sedangkan menurut Sutrisno (2001) menentukan responden penelitian adalah ada dua metode dalam menentukan responden populasi dan sampel. Dari pengertian tersebut dapat ditarik kesimpulan bahwa metode dalam menentukan responden adalah sautu cara yang digunakan untuk menentukan orangorang yang ditunjuk untuk menjawab dan memberikan keterangan terhadap masalah yang diteliti baik secara tertulis ataupun lisan. Langkah-langkah yang dilakukan dalam pengolahan usabilitas menggunakan Nielsen Attributes of Usability (NAU) Questionnaire:

1. Pengambilan Data dengan Kuesioner Setelah ditentukan, langkah selanjutnya adalah melakukan pengambilan data dengan memberikan kuesioner kepada para mahasiswa di Universitas $\mathrm{X}$ dengan jumlah responden ditentukan dengan metode Slovin dengan batas toleransi kesalahan yang ditetapkan adalah $5 \%$.

$$
n=\frac{N}{\left(1+N(e)^{2}\right)}
$$

Keterangan :

$\mathrm{n}=$ JumlahSampel

$\mathrm{N}=$ Jumlah Total Populasi

e $=$ Batas Toleransi Error

2. Uji Statistik Deskriptif

Statistik deskriptif adalah statistik yang digunakan untuk menganalisis data dengan cara mendeskripsikan atau menggambarkan data yang telah terkumpul sebagaimana adanya tanpa bermaksud membuat kesimpulan yang berlaku untuk umum atau generalisasi. Dalam statistik deskriptif antara lain adalah penyajian data melalui tabel, grafik, diagram lingkaran, pictogram, 
Yuana Delvika, Chalis .F Hasibuan dkk, Analisa Usabilitas Website Sistem Informasi Akademik Universitas X Menggunakan Nielsen Attributes Of Usability (NAU) Questionnaire

perhitungan modus, median, mean (pengukuran tendesi sentral), perhitungan desil, persentil, perhitungan penyebaran data melalui perhitungan rata-rata dan standar deviasi, perhitungan persentase. (Sugiyono, 2009: 207-208). Pada penelitian ini penyajian data menggunakan tabel dan analisis datanya menggunakan mean.

$$
M=\frac{\varepsilon X}{N}
$$

Keterangan :

$\mathrm{M}$ : Mean

$\mathrm{X}$ : Nilai

$\mathrm{N}$ : Jumlah Responden

3. Uji Validitas dan Reliabilitas Kuesioner

Langkah selanjutnya adalah uji validitas dan reliabilitas kuesioner. Tujuan dari pengujian ini adalah untuk memastikan bahwa kuesioner yang digunakan telah valid dan reliabel agar dapat dilakukan analisis selanjutnya.

Pengujian validitas dapat menggunakan persamaan korelasi Product Moment, dengan rumus adalah sebagai berikut:

$$
\mathbf{r}=\frac{\mathbf{n} \sum \mathbf{x y}-\left(\sum \mathbf{X}\right)\left(\sum \mathbf{Y}\right)}{\sqrt{\left[\mathbf{n} \sum \mathbf{X}^{2}-(\mathbf{X})^{2}\right]\left[\mathbf{n} \sum \mathbf{Y}^{2}-\left(\sum \mathbf{Y}\right)^{2}\right.}}
$$

Keterangan : $r=$ koefisien korelasi product momen

$$
\begin{aligned}
& \text { X = skor tiap pertanyaan / item } \\
& \mathrm{Y}=\text { skor total } \\
& \mathrm{N}=\text { jumlah responden }
\end{aligned}
$$

Sedangkan, uji reliabilitas dapat diperoleh dengan menggunakan rumus Alpha Cronbach, yaitu:

$$
r_{11}=\left[\frac{K}{k-1}\right]\left[1-\frac{\sum \sigma_{b}^{2}}{\sigma_{t}^{2}}\right]
$$

Keterangan $: r_{11}=\quad$ reliabilitas kuesioner

$$
\begin{gathered}
\mathrm{K}=\text { banyaknya butir pertanyaan } \\
\sum \sigma_{b}^{2}=\text { jumlah variansi butir } \\
\sigma_{t}^{2}=\text { variansi }
\end{gathered}
$$

\section{Hipotesis}

Hipotesis adalah jawaban yang bersifat sementara terhadap masalah penelitian yang kebenarannya masih lemah, sehingga harus diuji secara empiris. Menurut sugiyono hipotesis merupakan jawaban sementara terhadap rumusan masalah penelitian (Sugiono, 2008).

Dari definisi diatas maka dapat disimpulkan bahwa hipotesis adalah jawaban yang bersifat sementara terhadap rumusan masalah yang dapat diuji kebenarannya secaa empiris ada lima hipotesis yang diajukan dalam penelitian ini:

$\mathrm{HO}_{\mathrm{a}}=$ Learnability sebagai variabel independen tidak berpengaruh signifikan terhadap usability sebagai variabel dependen.

$\mathrm{H} 1_{\mathrm{a}}=$ Learnability sebagai variabel independen berpengaruh signifikan terhadap usability sebagai variabel dependen.

$\mathrm{H} \mathrm{b}_{\mathrm{b}}=$ Efficiency sebagai variabel independen tidak berpengaruh signifikan terhadap usability sebagai variabel dependen.

$\mathrm{H} 1_{\mathrm{b}}=$ Efficiency sebagai variabel independen berpengaruh signifikan terhadap usability sebagai variabel dependen.

$\mathrm{HO}_{\mathrm{c}}=$ Memorability sebagai variabel independen tidak berpengaruh signifikan terhadap usability sebagai variabel dependen.

$\mathrm{H} 1_{\mathrm{c}}=$ Memorability sebagai variabel independen berpengaruh signifikan 
terhadap usability sebagai variabel dependen.

$\mathrm{H}_{\mathrm{d}}=$ Errors sebagai variabel independen tidak berpengaruh signifikan terhadap usability sebagai variabel dependen.

$\mathrm{H} 1_{\mathrm{d}}=$ Errors sebagai variabel independen berpengaruh signifikan terhadap usability sebagai variabel dependen.

$\mathrm{H} 0_{\mathrm{e}}=$ Satisfaction sebagai variabel independen tidak berpengaruh signifikan terhadap usability sebagai variabel dependen.

$\mathrm{H} 1_{\mathrm{e}}=$ Satisfaction sebagai variabel independen berpengaruh signifikan terhadap usability sebagai variabel dependen.

\section{HASIL \& PEMBAHASAN}

Sampel adalah sebagian dari popolasi yang di ambil melalui cara-cara tertentu dan pada penelitian ini pengambilan sampel dilakukan dengan rumus slovin dengan tingkat ketelitian 95\% yaitu sampel yang akan di ambil di Universitas X sebagai berikut:

Mahasiswa/i

$$
\begin{aligned}
\text { n Mahasiswa } & =\frac{7239}{\left(1+(7239)(0,05)^{2}\right)} \\
& =379,9 \approx 380
\end{aligned}
$$

Hasil perhitungan validitas untuk setiap atribut pada kuesioner Mahasiswa ditunjukkan pada Tabel 1 :

Tabel 1.Hasil Uji Validitas

No Pertanyaan r hitung $\begin{gathered}\mathrm{r} \\ \text { table }\end{gathered}$

\section{Learnability}

Saya

mempelajari

website Sistem

1 Informasi $\quad 0.954 \quad 0.101 \quad$ Valid

Akademik

Universitas $\mathrm{X}$

dengan mudah

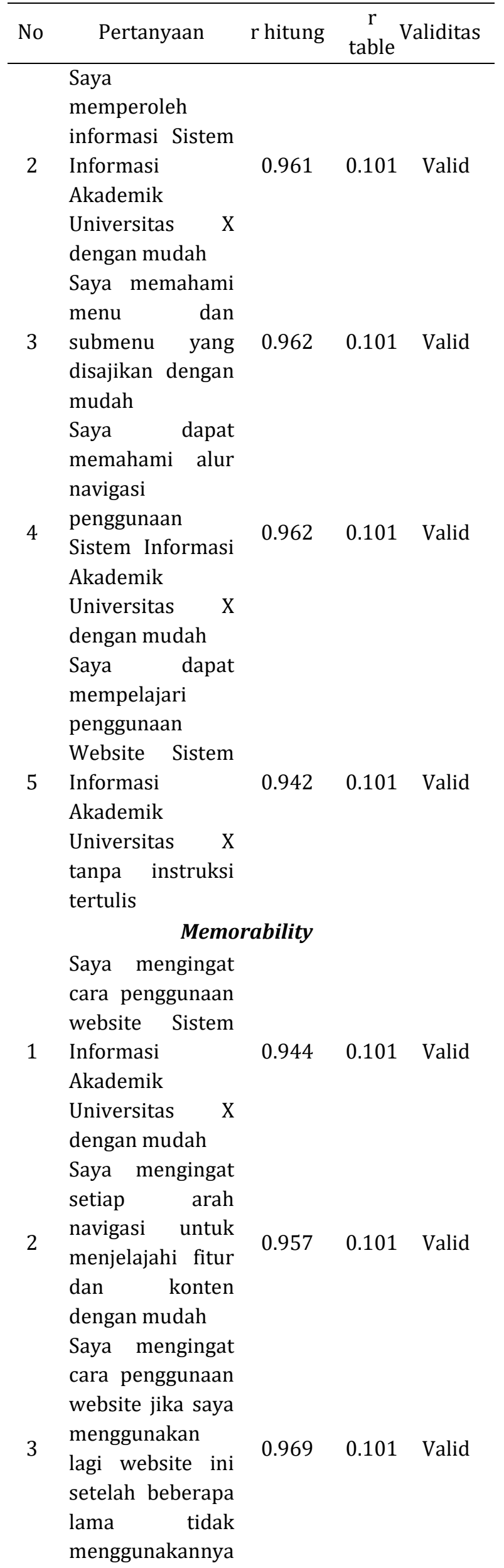


Yuana Delvika, Chalis .F Hasibuan dkk, Analisa Usabilitas Website Sistem Informasi Akademik Universitas X Menggunakan Nielsen Attributes Of Usability (NAU) Questionnaire

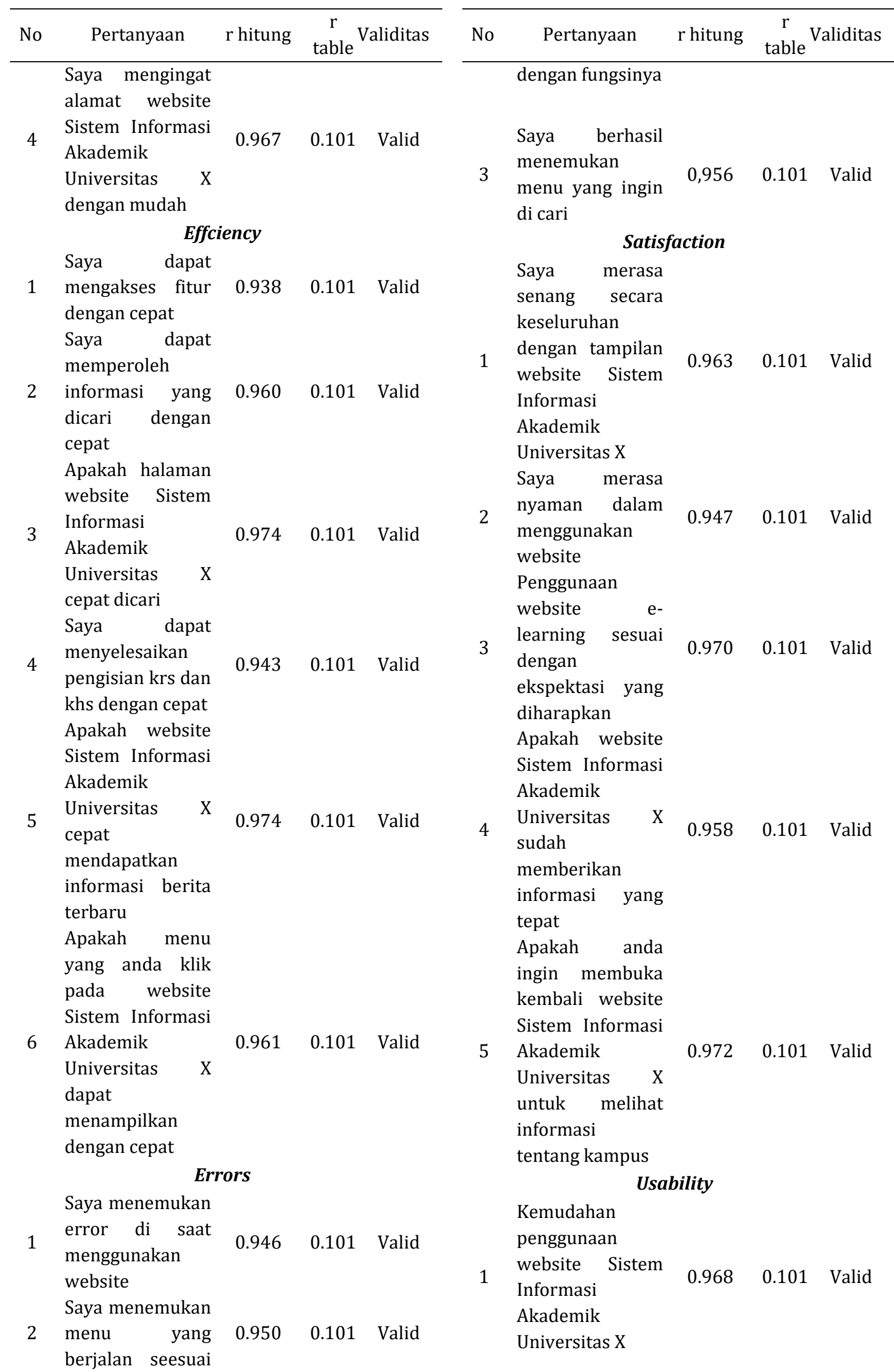




\begin{tabular}{|c|c|c|c|c|}
\hline No & Pertanyaan & r hitung & $\begin{array}{c}r \\
\text { table }\end{array}$ & Validitas \\
\hline 2 & $\begin{array}{l}\text { Kepuasan } \\
\text { tampilan fitur } \\
\text { dalam website } \\
\text { Sistem Informasi } \\
\text { Akademik } \\
\text { Universitas X }\end{array}$ & 0.961 & 0.101 & Valid \\
\hline 3 & $\begin{array}{l}\text { Kepuasan secara } \\
\text { keseluruhan } \\
\text { terhadap website } \\
\text { Sistem Informasi } \\
\text { Akademik } \\
\text { Universitas X }\end{array}$ & 0.950 & 0.101 & Valid \\
\hline
\end{tabular}

Sumber : Pengolahan Data

Uji reliabilitas dilakukan dengan menggunakan program SPSS versi 16.0dengan criteria sebagai berikut:

a. Jika nilai Cronbach's Alfa $\geq 0,6$ maka pertanyaan dikatakan reliabel

b. Jika nilai Cronbach's Alfa $\leq$ 0,6 maka pertanyaan dikatakan tidak reliabel

Tabel 2. Hasil Uji reliabilitas

\begin{tabular}{clccc}
\hline \multirow{2}{*}{ NO } & \multirow{2}{*}{ Variabel } & Cronbach's & R & \multirow{2}{*}{ Relfa } \\
& & Tabel & \\
\hline 1 & Learnability & 0.982 & 0.6 & Realibel \\
2 & Memorability & 0.980 & 0.6 & Realibel \\
3 & Efficiency & 0.984 & 0.6 & Realibel \\
4 & Errors & 0.958 & 0.6 & Realibel \\
5 & Satisfication & 0.983 & 0.6 & Realibel \\
6 & Usability & 0.967 & 0.6 & Realibel \\
\hline
\end{tabular}

Sumber : Pengolahan Data

Hasil uji normalitas data tidak berdistribusi normal maka untuk perhitungan selanjutnya dilakukan uji statistik non-parametrik. Karena data dalam penelitian ini bertipe ordinal maka akan dilakukan pengujian korelasi spearman. Untuk hasil uji korelasi spearman koesioner mahasiswa dapat dilihat pada tabel 3

Tabel 3. hasil uji korelasi spearman koesioner mahasiswa

NO Keterangan Correlation 2- Z

\begin{tabular}{|c|c|c|c|c|}
\hline NO & Keterangan & $\begin{array}{c}\text { Correlation } \\
\text { Coefficient }\end{array}$ & $\begin{array}{c}2- \\
\text { Tailed }\end{array}$ & $\begin{array}{c}\mathrm{Z} \\
\text { hitung }\end{array}$ \\
\hline 1 & $\begin{array}{l}\text { Korelasi } \\
\text { Learnability } \\
\text { Terhadap } \\
\text { Usability }\end{array}$ & 0,979 & 0,000 & 18.0842 \\
\hline 2 & $\begin{array}{l}\text { Korelasi } \\
\text { Memorability } \\
\text { Terhadap } \\
\text { Usability }\end{array}$ & 0,970 & 0,000 & 17.9088 \\
\hline 3 & $\begin{array}{l}\text { Korelasi } \\
\text { Effciency } \\
\text { Terhadap } \\
\text { Usability }\end{array}$ & 0,990 & 0,000 & 18.2987 \\
\hline 4 & $\begin{array}{l}\text { Korelasi } \\
\text { Error } \\
\text { Terhadap } \\
\text { Usability }\end{array}$ & 0,981 & 0,000 & 18.1232 \\
\hline 5 & $\begin{array}{l}\text { Korelasi } \\
\text { Satisfaction } \\
\text { Terhadap } \\
\text { Usability }\end{array}$ & 0,988 & 0,000 & 18.2597 \\
\hline
\end{tabular}

Sumber : Pengolahan Data

Berdasarkan hasil kusioner yang telah dilakukan penulis mengambil beberapa indikator yang perlu diperhatikan untuk di perbaiki berdasarkan modus yang terdapat pada tabel 4 berikut

Tabel 4. Indikator Tingkat Perbaikan

\begin{tabular}{ll} 
No & Indikator \\
\hline 1 & $\begin{array}{l}\text { Saya memahami alur navigasi penggunaan } \\
\text { Informasi Akademik Universitas X dengan mu }\end{array}$ \\
2 & $\begin{array}{l}\text { Saya ingin membuka kembali Website } \\
\text { Informasi Akademik Universitas X untuk n } \\
\text { informasi tentang kampus }\end{array}$ \\
3 & $\begin{array}{l}\text { Saya berhasil menemukan menu yang ingin di } \\
\text { dengan cepat }\end{array}$ \\
4 & $\begin{array}{l}\text { Saya dapat menyelesaikan pengisian krs dan l } \\
\text { dengan cepat } \\
\text { Website Sistem Informasi Akademik Universi1 } \\
\text { cepat mendapatkan berita terbaru }\end{array}$
\end{tabular}

Sumber : Pengolahan Data

Di identifikasi permasalahan dan perbaikan dari website Sistem Informasi Akademik Universitas X, berdasarkan hasil 
uji hipotesa pada setiap indikator usability memiliki hasil korelasi atau hubungan yang cukup kuat dengan artian apabila semakin ditingkatkan tiap indikatornya maka usability juga akan meningkat. Adapun usulan rancangan website Sistem Informasi Akademik Universitas X dapat dilihat pada gambar- gambar di bawah ini.

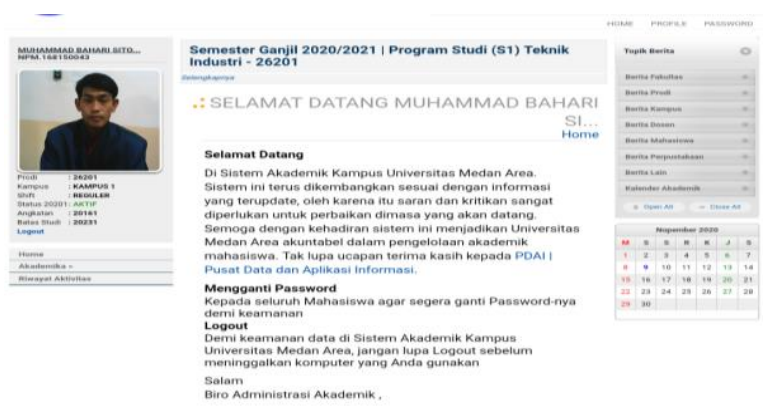

Gambar 1. Desain Awal Sistem Informasi Akademik Universitas

Sumber : Website

Adapun desain usulan rancangan website SISTEM INFORMASI AKADEMIK UNIVERSITAS $\mathrm{X}$ berdasarkan hasil penelitian adalah sebagai berikut



Gambar 2.Desain Usulan Sistem Informasi Akademik

Sumber : Pengolahan Data

\section{SIMPULAN}

Kesimpulan dari penelitian ini adalah :

1. Berdasarkan hasil uji statistik didapatkan hasil sebagai berikut :

Kuesioner mahasiswa hasil uji korelasi untuk kategori learnability memorability effciency Errors dan satisfaction terhadap usability $0,000<0,05$ maka berkorelasi. Untuk angka koefisien korelasi kategori satisfication, error, Learnability ,memorability dan efficiency terhadap usability memiliki nilai korelasi sangat kuat (0.76 - 0.99 korelasi sangat kuat), Untuk angka koefisien korelasi kategori apa saja terhadap usability memiliki nilai korelasi kuat (0.51 - 0.75 korelasi kuat), Untuk angka koefisien korelasi kategori apa saja terhadap usability memiliki nilai korelasi cukup $(0.26-0.50$ korelasi cukup). Dan untuk kriteria arah hubungan kategori learnability memorability effciency Errors dan satisfaction terhadap usability bernilai positif sehingga dapat diartikan sebagai jenis hubungan searah. Dengan demikian dapat disimpulkan bahwa learnability memorability effciency errors dan satisfaction bila semakin ditingkatkan maka usability juga akan meningkat.

2. Rekomendasi yang dapat diberikan terhadap website Sistem Informasi Akademik Universitas $\mathrm{X}$ dengan hasil evaluasi ini adalah sebagai berikut:

a. Pada layar desain usulan menu krs dan nilai menjadi menu utama sehingga lebih mudah dan efektif bagi mahasiswa yang ingin menyelesaikan proses pengisian krs dan melihat nilai yang sering pengguna buka pada website Sistem Informasi Akademik Universitas X.

b. Membuat menu search pada layar tampilan awal, untuk memudahkan pengguna mencari dengan cepat ataupun mengaplikasikan dengan cepat sesuatu hal tanpa mencari dan mencoba-coba mengklik menu dan submenu yang terdapat pada website Sistem Informasi Akademik Universitas X. 
c. Membuat menu email sehingga membuat pengguna mudah bertanya kepada pihak admin apabila terjadi kendala pada proses pemakaian, adanya ketidaktahuan pada proses pemakaian, adanya error dan lain-lain.

d. Membuat menu tata cara \& panduan untuk mempermudah bagi para mahasiswa baru dalam menjalankan alur navigasi website Sistem Informasi Akademik Universitas X dan memperoleh informasi tentang tata cara penggunaan yang baik dan benar.

\section{DAFTAR PUSTAKA}

Aprilian, Fenty Rizky (2014) Evaluasi Web Asability Pada Website Wiki-Budaya Berdasarkan Nielsen Model Dengan Metode User Testing Dan Teknik Heuristic Evaluation. Undergraduate Thesis, Institut Teknologi Sepuluh Nopember.

Arief, M. Rudianto. 2011. "Pemrograman Web Dinamis Menggunakan Php Dan Mysql". Andi :Yogyakarta

Dewi, I. K., Mursityo, Y. T., Dan Putri, R. R. M. (2018). Analisis Usabelity Aplikasi Mobile Pemesanan Layanan Taksi Perdan
Menggunakan Metode Webuse Dan Heuristic Evaluation. Jurnal Pengembangan Teknologi Informasi Dan Ilmu Komputer, Vol. 2, No 8 Agustus 2018, Universitas Brawijaya.

Khoirina, Fithrotu (2017). Evaluasi Web Usability Pada Modul Aplikasi Daftar Online Rumah Sakit Berdasarkan Nielsen Model Dengan Metode User Testing Dan Teknik Heuristic Evaluation (Studi Kasus: E-Health Rumah Sakit Umum Daerah Gambiran Kediri). Undergraduate Thesis, Institut Teknologi Sepuluh Nopember.

Kadafi, A. R. (2016). Evaluasi Usability Website Sekolah Islam Terpadu Nurul Fikri Depok Menggunakan Web Usability. Stmik Nusa Mandiri Jakarta, Jakarta Pusat.

Santoso, H. B. (2019). Perancangan Dan Usability Evaluation Prototipe Informasi Akademik Menggunakan Metode Rapid Application 48 Development. Jurnal Ilmiah Ilkominfo, Volume 2 No. 2 Juli 2019, Universitas Amikom Yogyakarta.

Sriwulandari, A., Hidayati, H., Dan Pudjoatmojo, B. (2014). Analisis Dan Evaluasi Aspek Usability Pada Web Hrmis Telkom University Menggunakan Usability Testing. Eproceedings Of Engineering, 1(1).

Sugiyono. 2011. Metode Penelitian Kuantitatif, Kualitatif Dan R\&D. Bandung:Afabeta

Sutabri, Tata. 2012. Analisis Sistem Informasi. Yogyakarta: Andi. 